\title{
The Nexus between Poor and Bad Governance, and Sub-National Conflicts in Africa
}

\author{
Fie David Dan-Woniowei \\ Department of Political Science, Faculty of Social Sciences, Niger Delta University, Wilberforce Island, Bayelsa State, Nigeria \\ Email: fieddanwoniowei@gmail.com
}

How to cite this paper: Dan-Woniowei, F. D. (2020). The Nexus between Poor and Bad Governance, and Sub-National Conflicts in Africa. Open Journal of Political Science, 10, 697-704.

https://doi.org/10.4236/ojps.2020.104040

Received: August 1, 2020

Accepted: October 17, 2020

Published: October 20, 2020

Copyright $\odot 2020$ by author(s) and Scientific Research Publishing Inc. This work is licensed under the Creative Commons Attribution International License (CC BY 4.0).

http://creativecommons.org/licenses/by/4.0/

Open Access

\begin{abstract}
Conflict has been attributed to Africa's developmental woes. Several causal factors have been advanced with the intent to unravel the origin, nature and stereotypes of conflicts in order to bring peace and stability, and development to the continent. However, most of such studies linking causal factors of conflicts relating to sub-national conflicts and development of the African region have not been very clear. This article establishes a link between poor and bad governance, and sub-national conflicts in Africa to encourage African states and their political leaders to embrace good governance as panacea to peace, stability and development of the continent. The linkage was constructed using secondary data relating to poor and bad governance, and sub-national conflicts in and outside the region of Africa.
\end{abstract}

\section{Keywords}

Poor and Bad Governance, Sub-National Conflicts, Africa

\section{Introduction}

One striking revelation of the African Governance Report (2019) is that there is absence of good governance, good peace, and sustainable development in most African nations. It implies that most African nations are poorly or badly governed, thereby facing security and development challenges. The problem is succinctly illustrated, thus:

“...Poor governance is Africa's Achilles, a shortcoming that is at the heart of virtually all the continent's problems" (Downie, 2014b).

"...Virtually every story coming out of the continent seems to showcase one atrocity or another" (National Interest, January 22, 2016).

“...Conflict is still Africa's biggest challenge in 2020" (Institute for Security 
Studies (ISS), January 6, 2020).

"...Africa has become more peaceful as well... modern conflicts in Africa are... highly localized, and they defy simplistic explanations based on stereotype...” (National Interest, January 22, 2016).

Absolutely, the problem of governance and conflicts are serious challenges to the African continent. It has negatively ordered the pace of development of many African states in recent decades. Particularly, the emergence of sub-national conflicts, which were believed to have metamorphosed from the state-to-state conflicts that preoccupied the life of the continent towards the end of the $20^{\text {th }}$ Century, is still ongoing in the continent (Annan, 2014). The problem has been worrisome to the extent that, many scholars and analysts of conflict and development orientations, have hurriedly concluded that the African continent in the $21^{\text {st }}$ Century will be politically more violent and unstable (Annan, 2014; Bellamy, 2014). Worried by it also, the African Union (AU) has urged the African political leadership to be more committed to implementing decisions and actions that would lead to peace, security and good governance to "silence the guns" by 2020 (African Governance Report, 2019).

The reality is that the guns are not yet silent, conflicts still persist and ravaging countries in the Maghreb region and parts of Sub-Saharan Africa. Nevertheless, parts of Africa have both experienced longer periods of peace and conflicts (National Interest, 2016). But conflicts that are sub-national in nature are still evident in mainly poorly and badly governed countries (Adetula, 2014). In the same vein, Crocker (2019), Annan (2014), and Downie (2014b) respectively, acknowledges that poor or bad governance in many African countries is one of the causal factors for majority of the continent's intra-state or localized (sub-national) conflicts.

Poor or bad governance is a condition in which the state lacks the capacity and effectiveness in regulatory quality for the eradication of societal challenges such as impoverishment, infrastructural development, corruption, insurgency and terrorism among others (Yagboyaju \& Akinola, 2019). In other words, poor governance is an extreme end condition of failure and collapse of governmental institutions and structures. The lesser to this is bad governance, which is the opposite of good governance. Bad governance is a situation of unfavourable relationship between government and segments of society in decision-making. In other words, it is a reflection of instability in political regimes. It could occur in various forms. For example, when operators of state systems refuse to uphold rule of law in governance or refuse to be accountable to the citizens for their actions can amount to crisis in the regime. Poor or bad governance is extremely damaging to the state's corrective role, particularly in the maintenance of peace and security, as well as the promotion of economic growth and wealth needed to confront poverty and improve human capital development (African Governance Report, 2019). In such situations, Crocker (2019) suggests that the political leadership should be held accountable for the good or ill of the society. 
From the insights presented, there is hardly any concrete evidence linking poor and bad governance to the problem of sub-national conflicts in Africa. Most of the perceptions examined casually presented the subject as a mere causative factor, and failed to show how or identify the strings linking the issue of sub-national conflicts in the African region. It is on this plank that this article constructs the concrete bridge linking poor and bad governance, and sub-national conflicts in Africa. It is also to underscore the reality of poor and bad governance being the major culprit to all Africa's unending challenges. In that context, the discourse is believed to serve as preventive measure to sub-national conflicts in Africa and other conflict prone areas of the world.

\section{The Nexus between Poor and Bad Governance, and Sub-National Conflicts in Africa}

It is the belief of many scholars of conflict and development orientations that the continent's developmental woes are as a result of poor and bad governance in many African countries. Such claims may be true or false depending on the side of the lens one views the continent's security and development situation. However, responding to such claims on the African discourse, Adetula (2015) caution that linking conflict and underdevelopment is quite a complex and difficult endeavour, and should be guided by adequate knowledge. Nevertheless, Ibaba (2020) acknowledges that poor and bad governance is the hallmark of many African countries. In addition, ISS (2020) describes the situation as Africa's biggest challenge in the past few decades. Going by such perceptions, it is important to further demystify what poor and bad governance actually mean, and how does it constitute Africa's biggest shortcoming? Or, on the contrary, what is good governance?

\subsection{Poor and Bad Governance}

The phrases "poor and bad governance" or "good governance" simply describe the quality and characteristics of the concept of governance. What then is governance? Governance like many other concepts in political science lacks a precise definition (Ibaba, 2020; Ali, 2015). However, it simply refers to a process of decision-making (policy formulation) and the process by which the decisions (policies) are implemented (or not implemented) (Ali, 2015). More explicitly, Ibaba (2020), and Adetoye \& Omiluisi (2016) considers the concept of governance as the process whereby public or governmental institutions at both national or central, and local levels conduct public affairs, manage public resources, and guarantee the realization of the public or common good of society. In that sense, the formal and informal processes, methods and structures put in place to arrive at outcomes can be poor, bad or good (Ibaba, 2020). The machinery includes the government in power at all levels, and its institutions (state actors) and the civil society (non-state actors). The mutual understanding between the formal and informal sectors of governance is critical for peace, stabili- 
ty and development of any country or region. In other words, the nature (quality and characteristics) of the governance architecture in any society determines its level of peace, stability, and development (Crocker, 2019). Pertaining to Africa, Lamb (2014) observed that the continent lacks peace and stability because of tension between the state and non-state actors. What this means is that the political leadership (state actors or government) in many African countries does not encourage citizens' participation in the conduct of state affairs.

Citizens involvement in the affairs of a state is critical for purposes of transparency and accountability, effectiveness and efficiency, and strategic response to individual or societal actions, as well as fairness and equitable distribution of available resources based on the rule of law (Ibaba, 2020; Ali, 2015). In addition, governance imposes on the political leadership of a country to assure its citizens that it will not be involved in corrupt practices (Ali, 2015). Furthermore, governance imposes on the political leadership of a nation to give priority and attention to the rights of minorities and the vulnerable of society (Ali, 2015).

This is essential because it is through governance that non-state actors determine whether there are durable links between the operators of the state (i.e. leadership at all levels exercising political authority) and the wider society they sworn to govern (Crocker, 2019). The durable links between the state and its citizens is a function of legitimacy. What legitimate authority emphasizes is the acceptance of laws and norms rather than arbitrary use of state power and resources. It thus suggests that any governmental action must comply strictly to the legitimate demands of the citizens. To comply or not to comply depends on the underlying principles of governance adjudged good, or poor and bad (Ibaba, 2020; Iyad, 2019). Good governance canvasses transparent and efficient use and management of state power and resources for the interest of all in society. The contrary is poor and bad governance. Both actually define the political culture (which is the resolve for violence and conflicts or peace, stability and development) of a nation.

Poor and bad governance, or good governance is a function of leadership quality, character and conduct in line with citizens' expectations and norms of society. Thus, poor and bad governance represents a governance condition in a country that defy all known principles (qualities, characteristics and conduct) of government. Ibaba (2020) aptly describes it as a governance condition where the state and its institutions at national, regional and local levels is predatory to majority of the citizens. More explicitly, poor and bad governance is a governance condition in a country in which the political leadership is unpatriotic, dishonest, indiscipline, corrupt, and lacks vision in the conduct of government business of allocation and distribution of resources in an unjust, unfair and inequitable manner, as well as not taken advantage of available opportunities for the development and promotion of common good of society (Ibaba, 2020). Furthermore, poor and bad governance connotes inefficient management of state power and scarce resources as opposed to the common good of society (Ibaba, 2020). How- 
ever, a governance condition that is poor and bad is adjudged by the citizens based on the rule of law.

\subsection{Sub-National Conflicts}

The leadership of the African continent at all levels considered the year 2020 to end most of its developmental challenges. However, the year 2020 has come and conflicts still remain one of the continent's greatest challenges (ISS, 2020). The recent challenges (conflicts) are not among states; they are local or intra-state in origin and nature (i.e. sub-national), involving section(s) of citizens against a state or central government over grievances and frustrations often arising from poor and bad governance. They are mostly widespread, enduring, and deadly in recent years (Parks, Colleta, \& Oppenheim, 2013). Countries with such conflicts experiences in Africa include Libya, Eritrea, Somalia, Sudan, South Sudan, Central African Republic (CAR), Democratic Republic of Congo (DRC), Equatorial Guinea, Cameroon, Mali, Chad and Nigeria (ISS, 2018; Downie, 2014a; Bellamy, 2014). ISS (2020) reveal that Africa alone in 2019 (up to 30 November) had about 21,600 incidents of armed conflicts in the global statistics of conflict incidents. The Institute (ISS, 2020) also reveals that the continent recorded in the same period of 2018, numbering 15,874, which represents 30\% increase in 2019. These alarming statistics are mostly imposed on the continent by non-state armed groups of insurgents, terrorists and criminals at war with a state, itself or another armed group within or across international boundary (Downie, 2014a).

The root cause(s) and the stereotype(s) of sub-national conflicts are from country to country or across regions. However, for the African region, the identified causes include poverty, corruption, wealth inequality, poor and bad governance, human rights violation, ethnic marginalization, teeming youth population, and small arms proliferation (Downie, 2014a; Annan, 2014). No doubt, all the causal factors in the list play significant roles in Africa's conflict situation. However, in the context of this article, poor and bad governance has been deemed the major causal factor to many of the evils confronting the African continent.

The question is, how? Or in what way(s)?

\subsection{Strings of the Nexus}

The African Governance Report (2019) declared that public governance is key to assessing implementation of set targets in the continent. It has been earlier stated that Africa is bereft of good governance. It has also been stated that the absence of good governance has made it difficult for many governments of African states to perform the corrective intervention role, particularly, in the areas of maintenance of peace and security, stimulation and production of economic growth and development of society. In examining the factor of teeming African youth population in the context of governance, Goldin (2014) pointed out that roughly 
$60 \%$ of Africa's 1 billion citizens are youths (i.e. persons within 30 years of age), and the number is expected to double in the continent by 2050 to 600 million. Hitherto, African governments instead of investing on this huge youth population for growth and development, pays lip service, and left it uncared for. Many governments of African states could not provide meaningful opportunities for the youths to realize their aspirations and take part in the growth and development of the continent. Goldin (2014) further affirms that the youth population is perpetually side-lined with no sign of improvement of their wellbeing; they are left to live in adversity, insecurity, and poverty, and faces various social, economic, political and technological vulnerabilities. In addition, Goldin (2014) stated that it is on the shoulders of this neglected youth population that the breaking or sustaining cycles of poverty rests to give the desired quality of life to their parents, siblings and children. The hidden truth about this development is that the various communities are on high risk as well as the continent's growth and development process is thwarted. This is because many African governments fail to harness their natural endowments such as creativity, tenacity, talent, courage, among others for growth and development. In other words, such youthful energies are being diverted to creating security challenges in the continent. For Downie (2014b), it is the uncared-for youth population that forms the locus for instability in the continent.

Another possible string tying poor and bad governance to sub-national conflicts could be traced to weak and ineffective political leadership of most African states. The political leadership of such states lack the political will to initiate and achieve the type of reforms that can prevent dictatorship, corruption, economic decline, conflicts, as well as reduce the inequality gap between the rich and poor, or the ruling elites and rest members of society. Poor and bad governance creates and greatly enhances the gap of wealth inequality among citizens of many African states. The gap between the rich and the poor or the governing elites and rest of society even in some resource-rich countries of the African region is quite alarming by the day. In other words, wealth inequality is a looming concern in many African states. The situation provides a breeding ground for crimes including banditry, terrorism, sea piracy, oil theft, kidnapping, armed robbery, cattle rustling, among others in the continent. Downie (2014b) captured the prevailing wealth inequality gap and frustrations among the citizens of the continent in this manner, "impressive headlines of GDP growth figures in many African countries fail to capture the anger and depression rising among the have-nots". To curb this challenge, Downie (2014b) suggests that African governments (political leadership) at all levels (regional, national, local) must approach governance with more seriousness and dedication or continue to face unending challenges from their increasingly emboldened, empowered, and interconnected citizens. The reason is that political leaders are the primary holders, controllers and distributors of state power and resources in a particular institution and/or territory (Van Wyk, 2007). 


\section{Conclusion}

The African continent has been a theatre of many sub-national conflicts in recent decades. It has been established that poor and bad governance in many African countries is the major contributor to the enduring sub-national conflicts in the continent. It was also argued that due to poor and bad governance in many African states, the exuberant African youth population had been grossly undermined with virtually no hope in sight for their welfare. Poor and bad governance creates and promotes widespread unemployment and wealth inequality gap among citizens of many African societies (Kreutz, 2012). A condition deemed to have triggered the young African population to engage in various crimes such as banditry, terrorism, kidnapping, oil theft among others to realize their family or social, economic and political aspirations. In order to reduce the spate and/or resolve most of the ongoing subnational conflicts in the continent, it is imperative to remind African governments that the young population are supposedly the future experienced doctors, teachers, lawyers, entrepreneurs, engineers, farmers, journalists, and political leaders of the continent. Therefore, it is vital for African states and governments to make adequate plans for their youth population. In other words, they should be given opportunity to realize their natural endowments, reduce the inequality gap between the rich and poor of her citizens. Such imperatives of good governance can curb the menace of sub-national conflicts in the continent. Sub-national conflicts occasioned by poor and bad governance had greatly hindered the growth and development of many African states.

\section{Conflicts of Interest}

The author declares no conflicts of interest regarding the publication of this paper.

\section{References}

Adetoye, D., \& Omiluisi, M. O. (2016). The Symmetrical Relationship between Good Governance and Development. International Journal of Economics and Management, 4, 572-581.

Adetula, V. A. O. (2015). African Conflicts, Development and Regional Organisations in the Post-Cold War International System. In The Annual Claude Ake Memorial Lecture (pp. 1-73). Lecture, NORDISKA AFRIKA INSTITUTE, Uppsala, Swede.

African Governance Report (2019). Agendas 2063 \& 2030: Is Africa on the Track? London: MO Ibrahim Foundation.

https://mo.ibrahim.foundation/sites/default/files/2019-10/African\%20Governance\%20 Report\%202019.pdf

Ali, M. (2015). Governance and Good Governance: A Conceptual Perspective. The Dialogue, 10, 65-77.

Annan, N. (2014). Violent Conflicts and Civil Strife in West Africa: Causes, Challenges and Prospects. Stability: International Journal of Security and Development, 3, 1-16. https://doi.org/10.5334/sta.da

Bellamy, W. M. (2014). African Security: Time for a Change in Doctrine? In R. Downie 
(Ed.), Africa in the Wider World (pp. 4-6). A Report of the CSIS African Programme, Centre for Strategic \& International Studies (CSIS), Lanham, MD: Rowman \& Littlefield.

Crocker, C. A. (2019). African Governance: Challenges and Their Implications. https://www.hoover.org/research/african-governance-challenges-and-their-implications

Downie, R. (2014a). Africa in the Wider World (pp. 1-37). A Report of the CSIS African Programme, Centre for Strategic \& International Studies (CSIS), Lanham, MD: Rowman \& Littlefield.

Downie, R. (2014b). Africa Diverging: The Struggle to Keep Pace with a Fast-Evolving Continent. In R. Downie (Ed.), Africa in the Wider World (pp. 1-3). A Report of the CSIS African Programme, Centre for Strategic \& International Studies (CSIS), Lanham, MD: Rowman \& Littlefield.

Goldin, N. (2014). Banking on Africa's Youth. In R. Downie (Ed.), Africa in the Wider World (pp. 31-33). A Report of the CSIS African Programme, Centre for Strategic \& International Studies (CSIS), Lanham, MD: Rowman \& Littlefield.

Ibaba, S. I. (2020). Rethinking the Narrative: Oil, Federalism and Development in the Niger Delta. In 5th (Combined) Convocation Lecture (pp. 1-77). Niger Delta University (NDU) Publishing Ltd.

Institute for Security Studies (ISS) (2018). Violence in Africa: Trends, Drivers and Prospects to 2023 (pp. 1-39). Africa Report, August 12.

Institute for Security Studies (ISS) (2020). Conflict Is Still Africa's Biggest Challenge in 2020. https://reliefweb.int/report/world/conflict-still-africa-s-biggest-challenge-2020

Iyad, D. (2019). Good Governance for Sustainable Development. MPRA Paper No. 92544. https://mpra.ub.uni-muenchen.de/92544

Kreutz, J. (2012). Dismantling the Conflict Trap: Essays on Civil War Resolution and Relapse. Report No. 96, Uppsala: Department of Peace and Conflict Research, Uppsala University.

Lamb, R. D. (2014). State Building Challenges in Africa. In R. Downie (Ed.), Africa in the Wider World (pp. 24-25). A Report of the CSIS African Programme, Centre for Strategic \& International Studies (CSIS), Lanham, MD: Rowman \& Littlefield.

National Interest (2016). The Wars Ravaging Africa in 2020. https://nationalinterest.org/blog/the-buzz/the-wars-ravaging-africa-2016-14993

Parks, T., Colletta, N. J., \& Oppenheim, B. (2013). The Contested Corners of Asia: Subnational Conflict and International Development Assistance. San Francisco, CA: Asia Foundation.

Yagboyaju, D. A. \& Akinola, A. O. (2019). Nigerian State and the Crisis of Governance: A critical Exposition. SAGE Open, 9, 1-10. https://doi.org/10.1177/2158244019865810

Van Wyk, J. A. (2007). Political Leaders in Africa: Presidents, Patrons or Profiteers? Occasional Papers Series No. 21, Mount Edgecombe: The African Centre for Constructive Resolution of Disputes (ACCORD), South Africa. 